\title{
Implementasi Pasal XX (b) dan (g) General Agreement on Tariffs and Trade dalam Penyelesaian Sengketa di World Trade Organisation
}

\author{
Sri Wartini \\ Fakultas Hukum Universitas Islam Indonesia \\ Jl. Tamansiswa No. 158 Yogyakarta \\ tiniwandita@yahoo.co.id
}

\begin{abstract}
There is a mutual relation between international trade and environment. International trade may give negative effects to the environment. The problems that will be studied are, first, how is the implementation of Article XX (b) and (g) of GATT in the dispute settlement at WTO? Second, why is there differences in interpretation method toward Article XX (b) and (g) of GATT by Panel and Appellate Body in dispute settlement at WTO? This research os a normative research and is analyzed qualitatively. The result of the research concludes that: first, panel and Appellate Body have differences in implementing Article $X X(b)$ and $(g)$ of GATT. This is caused by the different interpretation done by Panel and Appellate Body; second, the difference in the interpretation of Article XX (b) and (g) of GATT by Panel and Appellate Body in the settlement of those three cases is resulted from the lack of understanding of the Panel on the interpretation way as stipulated in Article 2(3) of DSU and lack of partisanship from the Panel to the importance of health, plants, animals, and environment protections.
\end{abstract}

Key words: International trade, panel, appellate body, negative effects.

\begin{abstract}
Abstrak
Ada suatu hubungan timbal balik antara perdagangan internasional dan lingkungan. Perdagangan internasional dapat menimbulkan dampak negatif terhadap lingkungan. Permasalahan yang hendak diteliti, pertama, bagaimanakah implementasi Pasal XX (b) dan (g) GATT dalam penyelesaian sengketa di WTO? Kedua, mengapa terjadi perbedaan metode penafsiran Pasal XX (b) dan (g) GATT oleh Panel dan Appellate Body dalam penyelesaian sengketa di WTO? Penelitian ini merupakan penelitian normatif dan dianalisa secara kualitatif. Hasil penelitian ini menyimpulkan: pertama, panel dan Appellate Body memiliki perbedaan dalam penerapan Pasal XX (b) dan (g) GATT. Hal ini disebabkan adanya perbedaan penafsiran/interpretasi yang yang dilakukan oleh Panel dan Appellate Body; Kedua, perbedaan penafsiran implementasi Pasal XX (b) dan (g) GATT oleh Panel dan Appellate Body dalam penyelesaian ketiga kasus tersebut disebabkan karena kurangnya pemahaman Panel terhadap cara interpretasi yang diatur dalam Pasal 2(3) DSU dan kurang adanya keperpihakan Panel terhadap kepentingan perlindungan kesehatan, tumbuhan, hewan, dan lingkungan.
\end{abstract}

Kata kunci : Perdagangan internasional, panel, appellate body, dampak negatif. 


\section{Pendahuluan}

Berbagai jenis komoditi telah memasuki pasar internasional dengan berbagai dampak yang ditimbulkannya. Konflik pun sering muncul dalam hubungan perdagangan antar negara, baik itu dipicu oleh kepentingan protectionism ataupun karena alasan perlindungan lingkungan. Para ekonom, ahli lingkungan maupun ahli hukum internasional sejak $1970^{1}$ telah menyadari adanya konflik antara perdagangan internasional dan perlindungan lingkungan.

Tidak dapat dipungkiri perdagangan internasional dapat menyebabkan dampak positif dan negatif ${ }^{2}$ terhadap lingkungan. Dampak positif perdagangan internasional antara lain: pertama, naiknya pendapatan perkapita menyebabkan orang lebih memperhatikan lingkungan daripada memikirkan bagaimana untuk memenuhi kebutuhan pokoknya, seperti sandang, pangan dan papan. Kedua, negara dengan income percapita yang lebih tinggi, akan memiliki sarana dan prasarana yang lebih baik dan memiliki kebijakan lingkungan yang lebih baik. ${ }^{3}$ Sedangkan, dampak negatif perdagangan internasional antara lain terjadinya eksploitasi yang berlebihan terhadap sumber daya alam.

Untuk mengurangi dampak negatif perdagangan internasional, dalam pembukaan pendirian WTO (The Establishing of World Trade Organisation) telah mengintegrasikan konsep pembangunan berkelanjutan (sustainable development) ${ }^{4}$ dalam perdagangan internasional. Pemanfaatan sumber daya alam harus sesuai dengan tujuan pembangunan berkelanjutan. WTO diharapkan memberikan nuansa baru dalam perdagangan internasional dengan terintegrasinya aspek lingkungan dalam perdagangan internasional. Berkaitan dengan ketentuan lingkungan yang

\footnotetext{
${ }^{1}$ Richard Skeen, "Will the WTO Turn Green? The Implication of Injecting Environmental Issues into the Multilateral Trading System” (Fall, 2004) vol. 17 Geo. Int'l Envtl. L. Rev. 166. See also, Debbie Collier and Charles Moitui, "Africa's Regulatory Approach to Biotechnology in Agriculture: An Opportunity to Seise Socio-Economic Concerns", (2009) vol. 17 (1) A.J.I.C.L. 31.

${ }^{2}$ Daniel C. Esty, Greening the GATT: Trade Environment and the Future, Washington Institute for International Economic, 1994, hlm. 42.

${ }^{3}$ Eric Neumayer, Greening Trade and Investment Environmental Protection Without Protectionism, Earthscan Publication Ltd, London, 2001, hlm. 105. See also, C. Ford Runge,Francois Ortalo-Magne and Philip Vande Kamp, Freer Trade, Protected Environment Balancing Trade Liberalization and Environmental Interest, Council on Foreign Relations Press, New York, 1994, hlm. 10.

${ }^{4}$ Philippe Sand, Principle of International Environmental Law, Manchester University Press, Manchester, 1995, hlm. 199-200. Pembangunan berkelanjutan mensyaratkan setiap generasi untuk melaksanakan kebijakan lingkungan yang menjamin generasi yang akan datang dapat menikmati lingkungan yang sehat dan sumber alam yang dinikmati oleh generasi yang sekarang. Dengan demikian perdagangan internasional yang dilakukan oleh negara harus menjamin keberlanjutan sumber daya alam, karena antara keduanya saling terkait dan saling mempengaruhi.
} 
terintegrasi dalam perdagangan internasional tertuang dalam Pasal XX GATT sebagai salah satu cover agreements di WTO.

Ketentuan Pasal XX GATT ayat (b) menyatakan ...necessary to protect human, animal or plant life or health; ...dan Pasal XX $(g)$ relating to conservation of exhaustible natural resources if such measures are made effective in conjucntion with restrictions on domestic production or consumption. Pasal XX ayat (b) ${ }^{5}$ dan (g) merupakan landasan hukum bagi negara untuk membuat kebijakan lingkungan dalam rangka untuk melindungi kesehatan manusia dan lingkungan serta untuk melakukan konservasi terhadap sumber daya alam. Akan tetapi dengan syarat, bahwa dalam membuat kebijakan tersebut tidak boleh menciptakan diskriminasi dalam perdagangan atau proteksi terselubung. ${ }^{6}$

Namun yang terjadi didalam praktik, negara-negara yang membuat kebijakan ataupun peraturan tentang perlindungan lingkungan nasional digunakan untuk proteksi terselubung negara pengimpor dan tidak sesuai dengan ketentuan Pasal XX GATT 1994 (selanjutnya akan disebut GATT). Oleh karena itu, kebijakan ataupun peraturan tersebut menimbulkan sengketa antara negara pengimpor dan pengekspor, sebagaimana dalam temuan penelitian ini ada tiga kasus yang diselesaikan di WTO berkaitan dengan Pasal XX (b) ataupun (g) GATT, yaitu Reformulated Gasoline, ShrimpTurtles, dan EC-Asbestos. Dalam penyelesaian kasus-kasus tersebut terjadi perbedaan penafsiran antara Panel dan Appellate Body dalam menerapkan Pasal XX (b) ataupun (g) GATT.

\section{Rumusan Masalah}

Berdasarkan uraian di atas, dirumuskan permasalahan sebagai berikut. Pertama, bagaimanakah implementasi Pasal XX (b) dan (g) GATT dalam penyelesaian sengketa di WTO? Kedua, mengapa terjadi perbedaan metode penafsiran Pasal XX (b) dan (g) GATT oleh Panel dan Appellate Body dalam penyelesaian sengketa di WTO?

${ }^{5}$ David P. Fidler, International Law and Infectious Deseases, Claredon Press, Oxford, New York, 1999, hlm.132-133.

${ }^{6}$ Dukgeun Ahn, "Environmental Disputes in the GATT/WTO : Before and After US-Shrimp Case", Mich.J. Int'l L., Vol. 20, Summer 1999, hlm. 820-821. 


\section{Tujuan Penelitian}

Penelitian ini bertujuan untuk, pertama, memahami dan menganalisis implementasi Pasal XX(b) dan (g) GATT dalam penyelesaian sengketa di WTO. Kedua, memahami dan menganalisis terjadinya perbedaan metode penafsiran Pasal XX (b) dan (g) GATT oleh Panel dan Appellate Body.

\section{Metode Penelitian}

Penelitian ini adalah penelitian yuridis normatif, karena yang akan dikaji adalah ketentuan perjanjian internasional yaitu Article XX (b) dan (g) GATT dan juga landasan hukum yang digunakan oleh Panel dan Appellate Body dalam penyelesaian sengketa Article XX GATT (b) dan (g), DSU dan Konvensi Wina 1969 tentang Perjanjian Internasional. Selain itu juga peraturan lingkungan nasional yang digunakan sebagai alasan pembenar bagi negara pengimpor untuk melarang masuknya suatu produk dari negara pengeksport.

Penelitian ini menggunakan pendekatan perundang-undangan (statute approach), pendekatan konsep (conceptual approach), pendekatan perjanjian international, dan pendekatan kasus (case approach).

Adapun bahan hukum yang digunakan meliputi bahan hukum primer, sekunder dan tersier. Bahan hukum yang diperoleh disajikan secara deskriptif dan dianalisa secara kualitatif

\section{Hasil Penelitian dan Pembahasan}

\section{Implementasi Pasal XX (b) dan (g) GATT oleh Panel dan Appellate Body dalam Penyelesaian Sengketa di WTO}

Penerapan Pasal XX (b) dan (g) dalam sengketa yang diajukan ke WTO ternyata terjadi perbedaan implementasi antara Panel dan Appellate Body. Hal ini merupakan suatu permasalahan yang harus dicari solusinya, mengingat kedua badan penyelesaian sengketa ini berada dalam suatu organisasi yang sama dan dalam suatu sistem hukum yang sama. Berikut ini hasil penelitian tiga kasus di WTO tentang pengimplementasian Pasal XX (b) dan (g) GATT. 


\section{United States-Standards for Reformulated and Conventional Gasoline (United States-Gasoline)}

Kongres Amerika Serikat telah memberlakukan Clean Air Act pada 1963 untuk mengontrol polusi udara yang terjadi karena proses industri dan juga karena asap kendaraan bermotor. ${ }^{7}$ Pada 1970 dibuatlah amandemen yang memberikan persyaratan yang lebih ketat terhadap kota-kota yang belum memenuhi standar sesuai dengan standar kualitas emisi nasional. Amandemen ini secara khusus memerintahkan Environmental Protection Agency (EPA) untuk menentukan standar emisi substansi bahan bakar (fuel content). ${ }^{8}$

\section{Issue Hukum}

Sengketa ini berkaitan dengan pengimplementasian ketentuan hukum nasional Amerika Serikat yang disebut Clean Air Act of 1990 (the "CAA") dan lebih khusus lagi pada penerapan ketentuan tersebut oleh EPA untuk mengontrol zat-zat beracun ataupun penyebab polusi yang disebabkan oleh bensin (gasoline) baik yang disebabkan oleh bensin yang diproduksi di Amerika Serikat atau yang diproduksi di negara lain. Secara formal regulasi itu bernama "Regulation of Fuels and Fuel Additives - Standards for Reformulated and Conventional Gasoline".

Dalam sengketa ini, Panel diminta untuk memeriksa apakah ketentuan tentang bensin (Gasoline rule) yang dikeluarkan oleh pemerintah Amerika Serikat ini merupakan pelanggaran terhadap GATT dan apakah ketentuan tersebut masuk dalam kualifikasi pengecualian Pasal XX (b), (d) dan (g) yang diatur dalam Pasal XX GATT.

\section{Panel Report}

Berdasarkan fakta-fakta dan argumen yang diajukan oleh para pihak maka Panel memutuskan bahwa ketentuan yang dikeluarkan oleh Amerika Serikat bertentangan dengan Pasal III:4 GATT dan tidak masuk dalam ruang lingkup ketentuan pengecualian yang dimuat dalam Pasal XX GATT.

${ }^{7}$ T. Alana Deere, "Balancing Free Trade and the Environment: A Proposed Interpretation of GATT Article XX's Preamble”, Int'l Legal Persp, Vol. 10, Spring, 1998, 8 (1-28).

${ }^{8}$ Ibid. 


\section{Appellate Body Report}

Berdasarkan Report yang dibuat oleh Panel maka AB memutuskan bahwa: (a) Panel telah salah mengambil kesimpulan bahwa Baseline Establishment Rules yang terdapat dalam Part 80 Chapter 40 Federal Regulations tidak jatuh dalam ketentuan Pasal XX GATT (g); (b) Baseline Establishment Rules yang terdapat dalam Part 80 Chapter 40 Federal Regulations gagal untuk memenuhi persyaratan yang dimuat dalam preamble Pasal XX GATT. Appellate Body merekomendasikan kepada Badan Penyelesaian Sengketa WTO untuk meminta Amerika Serikat menyesuaikan ketentuan yang tertuang dalam baseline establishment rules contained in Part 80 of Title 40 of the Code of Federal Regulations dengan ketentuan GATT.

\section{United States-Import Prohibition of Certain Shrimp and Shrimp Products (Shrimp- Turtle)}

Semua kura-kura laut yang berada di wilayah perairan Amerika Serikat masuk dalam kualifikasi binatang yang dilindungi, dan termasuk dalam daftar list Endangered Species Act of 1973 (hereinafter ESA). ${ }^{9}$ ESA melarang penangkapan kura-kura langka di semua perairan Amerika dan di laut lepas kecuali yang memperoleh autorisasi dari Secretary of Commerse U.S. atau dari Secretary of the Interior (for sea turtles on land). ${ }^{10}$

\section{Issue Hukum}

Pada 1989, Amerika Serikat memperluas pemberlakuan ESA dengan memberlakukan Section 609 of Public Law 101-162.11 Section 609 ini memuat larangan impor terhadap udang yang dipanen dengan menggunakan teknologi yang dapat merusak habitat kura-kura. Namun secara lebih khusus Section 609 melarang impor udang yang ditangkap menggunakan alat yang dapat mengakibatkan tertangkapnya kura-kura laut atau jenis species lain yang dianggap langka. ${ }^{12}$

\footnotetext{
${ }^{9}$ Panel Report on United States-Import Probibition of Certain Shrimp and Shrimp Products, WT/DS58/R(May 15, 1998) 37 I.L.M.832(1998) http:// www.wto.org/english/tratop_e/dispu_e/58r00.pdf hereinafter Shrimp-Turtle Report), Viewed on 22 October 2009.

${ }^{10}$ Ibid.

${ }^{11}$ Ibid., Para. 2.7.

${ }^{12}$ Suzanne Pyatt, “The WTO Sea Turtle Decision”, vol. 26 (1999) Ecology L.Q. 819.
} 


\section{Panel Reports}

Keputusan Panel dalam kasus Shrimp-Turtle menyatakan bahwa Section 609 of Public Law 101-162 tidak konsisten dengan Pasal XI:1 GATT 1994, dan tidak dapat dibenarkan berdasarkan Pasal XX GATT 1994. Panel merekomendasikan bahwa Amerika Serikat harus menyesuaikan tindakan yang tertuang dalam Section 609 sesuai dengan kewajiban yang tertuang dalam kesepakatan WTO. ${ }^{13}$

\section{Appellate Body Report}

Berdasarkan alasan-alasan yang dikemukakan oleh Panel, maka Appellate Body berpendapat bahwa apa yang dilakukan oleh Amerika Serikat bukanlah merupakan pelanggaran terhadap ketentuan Pasal XX, karena apa yang dilakukan Amerika Serikat untuk perlindungan lingkungan dan tidak membedakan antara kapal asing dan kapal lokal, sehingga tindakan tersebut tidak dapat dikualifikasikan sebagai pelanggaran Preamble yang menciptakan perlindungan terselubung terhadap produk dalam negeri. ${ }^{14}$

Appellate Body: (a) Membatalkan temuan Panel yang menerima informasi dari non pemerintah yang tidak sesuai dengan ketentuan dalam DSU,15 (b) Appellate Body juga membatalkan temuan/keputusan Panel yang menyatakan bahwa tindakan Amerika Serikat tidak dalam ruang lingkup tindakan yang diperbolehkan Pasal XX dan pembukaannya, ${ }^{16}$ dan (c) Appellate Body berkesimpulan bahwa tindakan Amerika Serikat gagal untuk memenuhi ketentuan dalam pembukaan Pasal XX sehingga tidak memenuhi justifikasi Pasal XX GATT. ${ }^{17}$ Dengan demikian, Appellate Body merekomendasikan kepada Amerika Serikat untuk melakukan penyesuaian tindakan yang dilakukan tidak sesuai dengan ketentuan Pasal XI dan Pasal XX GATT.

\footnotetext{
${ }^{13}$ Ibid., Para. 8.1.
}

${ }^{14}$ WTO Appellate Body Report on United States-Import Probibition of Certain Shrimp and Shrimp Products, WT/ DS58/AB/R (October. 12, 1998), 38 I.L.M. 118 (1999) http://www.wto.org/english/tratop_e/disp_e/58abr.pdf (hereinafter Shrimp-Turtle AB). Viewed on 23 October, 2009.

${ }^{15}$ Ibid., Para. 187(a).

${ }^{16}$ Ibid., Para. 187(b).

${ }^{17}$ Ibid., Para. 187(c). 


\section{European Communities-Measures Affecting Asbestos and Asbestos-Containing Products (EC-Asbestos)}

Pada 24 Desember 1996, Perdana Menteri Perancis melarang masuknya asbestos dari negara lain dengan mengeluarkan Keputusan No. 96-1133. Keputusan ini di desain untuk melindungi masyarakat dari bahaya asbes berdasarkan studi yang dilakukan oleh France's National Institute for Health and Medical Research (INSERM). ${ }^{18}$ Studi ini menyimpulkan bahwa chrysotile asbestos mengandung racun (carcinogenic) yang dapat mengancam kesehatan pada masyarakat. ${ }^{19}$

\section{Issue Hukum}

Kanada menggugat Keputusan Perdana Menteri Perancis tentang larangan impor asbestos dari Kanada yang efektif berlaku mulai Januari 1997. Ekspor ini sangat penting bagi Qubec (Kanada) sebagai penghasil asbestos. Sebetulnya Keputusan ini didasarkan karena adanya sifat atau karakteristik chrysotile asbestos yang dapat menyebabkan keracunan (carcinogenic characteristics). Larangan ini diberlakukan untuk jenis barang yang sama tanpa membedakan perbedaan asal-usul asbes baik dari dalam negeri ataupun dari Qubec. ${ }^{20}$

\section{Panel Report}

Pertama, Panel menyatakan bahwa keputusan yang dibuat oleh Perancis tidak masuk dalam ruang lingkup ketentuan TBT Agreement. Akan tetapi karena Kanada tidak menuntut adanya penyesuaian keputusan yang dilakukan oleh Perancis dengan TBT Agreement, maka Panel tidak memberikan rekomendasi atas pernyataan tersebut.

Kedua, Panel menyatakan bahwa chrysotile asbestos yang terbuat fibre maupun yang dari semen adalah sama atau dapat disebut "like product" menurut pengertian Pasal III:4 GATT. ${ }^{21}$ Ketiga, karena kedua jenis asbes ini dinyatakan serupa maka Panel menyatakan bahwa keputusan tersebut bertentangan dengan Pasal III:4 GATT 1994. Namun demikian, berdasarkan penemuan Panel pada Section VIII.E.4, ${ }^{22}$ Panel berkesimpulan bahwa keputusan tersebut yang membedakan produk asbes yang

\footnotetext{
${ }^{18}$ Ibid., Para. 3.11.

${ }^{19}$ Ibid.

${ }^{20}$ Sydney M. Cone, "The Asbestos Case and Dispute Settlement in the World Trade Organisation: The Uneasy Relationship between the Panel and the Appellate Body”, 2001, vol. 23, Mich. J. Int'l L., 105.

${ }^{21}$ Ibid., Para. 9.1(b).

${ }^{22}$ Ibid., Para. 9.1(c).
} 
mengandung racun merupakan pengecualian berdasarkan Pasal III:4, dan dibenarkan berdasarkan ketentuan Pasal XX GATT beserta Preamble-nya.

Akhirnya Panel berkesimpulan bahwa berdasarkan penemuan dalam SectionVIII.F menyatakan bahwa Kanada tidaklah dirugikan berdasarkan ketentuan Pasal XXIII:1(b) GATT. ${ }^{23}$ Panel meyatakan bahwa Keputusan (Decree) yang dikeluarkan oleh Perdana Menteri Perancis tidak bertentangan dengan Pasal XX (b) GATT.

\section{Appellate Body Report}

Kanada melakukan banding atas putusan Panel kepada Appellate Body pada 12 Maret 2001. Appellate Body menjawab pertanyaan yang muncul dalam proses pengambilan keputusan dalam Panel, yaitu: Apakah sengketa asbestos ini dapat dijadikan jurisprudensi hijau (green jurisprudence) dalam GATT di masa yang akan datang. ${ }^{24}$ Adapun alasan-alasan yang dikemukakan oleh Appellate Body dalam Report-nya sebagai berikut :

Pertama, Appellate Body membatalkan putusan Panel yang dimuat dalam paragraf 8.72(a) Panel Report, bahwa TBT Agreement 25 "tidak dapat diterapkan berkaitan dengan Keputusan yang dikeluarkan oleh Perancis mengenai larangan masuknya asbes dari Kanada ke pasar Perancis. Hal ini disebabkan keputusan tersebut tidak termasuk dalam ruang lingkup Annex 1.1 TBT Agreement", dan secara keseluruhan tidak menyangkut masalah regulasi teknis (technical regulation) sebagaimana yang dimaksud dalam TBT Agreement. ${ }^{26}$

Kedua, Appellate Body menyatakan bahwa penemuan Panel (Panel's findings) dalam paragraph 8.132 dan 8.149 Panel Report, yang menyatakan bahwa tidaklah tepat untuk mengkaitkan masalah kesehatan yang berkaitan dengan chrysotile asbestos fibres dalam menentukan serupa (likeness) tidaknya produk berdasarkan ketentuan Pasal III:4 GATT 1994, ${ }^{27}$ serta untuk menentukan serupa tidaknya cement-based products containing chrysotile asbestos fibres atau PCG fibres.

\footnotetext{
${ }^{23}$ Ibid., Para. 9.1(e).

${ }^{24}$ Appellate Body Report on European Communities-Measures Affecting Asbestos and Asbestos-Containing Products (hereinafter EC-Asbestos), Wt/DS135/AB/R. Para. 192.

${ }^{25}$ Ibid., Para. 192(a).

${ }^{26}$ Ibid.

${ }^{27}$ Ibid., Para. 192(b).
} 
Ketiga, Appellate Body membatalkan penemuan Panel yang dimuat dalam paragraf 8.144 Panel Report, yang menyatakan bahwa chrysotile asbestos fibres dan PCG fibres adalah produk yang serupa (like products) berdasarkan ketentuan Pasal III:4 GATT 1994;dan menyatakan bahwa Kanada tidak dapat memberikan bukti yang memadai bahwa fibres tersebut adalah produk yang serupa berdasarkan Pasal III:4 GATT. $^{28}$

Keempat, Appellate Body membatalkan penemuan Panel yang dimuat dalam paragraph 8.150 Panel Report, yang menyatakan bahwa cement based products containing chrysotile asbestos fibres dan cement-based products containing PCG fibres adalah produk yang serupa berdasarkan Pasal III:4 GATT ; dan menyatakan bahwa Kanada tidak dapat membuktikan bahwa produk itu serupa berdasarkan Pasal III:4 GATT. ${ }^{29}$

Kelima, sebagai konsekuensi Appellate Body membatalkan penemuan Panel yang dimuat dalam paragraf 8.158 Panel Report, yang menyatakan bahwa tindakan yang dilakukan oleh Perancis tidak konsisten dengan Pasal III:4 GATT. ${ }^{30}$

Keenam, Appellate body mendukung penemuan Panel yang dimuat dalam paragraf 8.194, 8.222 dan 8.223 Panel Report, yang menyatakan bahwa tindakan tersebut dipandang perlu untuk melindungi kesehatan manusia atau kesehatan (to protect human ... life or health $)^{31}$ dalam artian Pasal XX(b) GATT 1994; dan menyatakan bahwa apa yang dilakukan Panel sesuai dengan ketentuan Pasal 11 DSU dalam mengambil keputusan tersebut.

Ketujuh, Appellate Body juga mendukung penemuan Panel yang dimuat dalam dalam paragraf 8.265 dan 8.274 Panel Report, yang menyatakan bahwa tindakan yang dilakukan merupakan tindakan sebab akibat yang dimaksudkan oleh Pasal XXIII:1(b) GATT. $^{32}$

Appellate Body berkesimpulan bahwa Kanada telah gagal untuk membuktikan bahwa tindakan yang dilakukan Perancis yang berupa Keputusan Perdana Menteri tersebut bertentangan dengan kewajiban yang dimuat dalam covered agreements. Akibatnya, Appellate Body tidak membuat rekomendasi terhadap Badan Penyelesaian sengketa WTO berdasarkan ketentuan Pasal 19(1) DSU. ${ }^{33}$

\footnotetext{
${ }^{28}$ Ibid., Para. 192(c).

${ }^{29}$ Ibid., Para. 192(d).

${ }^{30}$ Ibid., Para. 192(e).

${ }^{31}$ Ibid., Para. 192(f).

${ }^{32}$ Ibid., Para. 192(g).

${ }^{33}$ Ibid., Para. 193.
} 


\section{Perbedaan Metode Penafsiran Pasal XX (b) dan (g) GATT oleh Panel dan Appellate Body}

WTO didirikan untuk mempromosikan perdagangan bebas, sehingga pengecualian prinsip-prinsip perdagangan bebas dibatasi sedemikian rupa. Para ahli perdagangan internasional bukanlah anti lingkungan akan tetapi mereka memiliki kewajiban untuk menyelesaikan sengketa di WTO sesuai dengan tujuan GATT, sehingga pada waktu mereka menginterpretasikan Pasal XX GATT yang merupakan pasal pengecualian dari ketentuan umum GATT, Panel menginterpretasikan secara sempit, dan cenderung untuk lebih mementingkan perdagangan internasional daripada perlindungan lingkungan.

Kalau ditelaah secara seksama, struktur kalimat dan rangkaian kata-kata yang termuat dalam Pasal XX GATT tidak mencantumkan bahasa yang mendukung untuk menginterpretasikan Pasal tersebut secara luas, sehingga Panel berpendapat bahwa interpretasi Pasaal XX (b) dan (g) GATT dinterpretasikan oleh Panel secara sempit dan tekstual. Sedangkan Appellate Body memang memberikan interpretasi yang lebih komprehensif, namun hasil akhir dari sengketa tersebut masih menunjukkan adanya keberpihakan Appellate Body terhadap penegakan prinsip-prinsip perdagangan internasional sesuai dengan tujuan dibentuknya GATT.

Menurut Appellate Body, metode penerapan Pasal XX GATT yang tepat ada 3 langkah yang harus dilakukan secara berurutan. Pertama, apakah kebijakan yang dikeluarkan oleh negara yang digugat masuk dalam kualifikasi untuk perlindungan terhadap manusia, hewan atau kehidupan tanaman dan kesehatan. Kedua, apakah kebijakan yang dikeluarkan oleh negara yang digugat perlu dilakukan untuk memberikan perlindungan terhadap manusia, hewan atau kehidupan tanaman dan kesehatan. Ketiga, apakah kebijakan tersebut dapat dibenarkan berdasarkan pembukaan Pasal XX GATT. ${ }^{34}$

\section{Perbedaan Penafsiran antara Panel dan Appellate Body dalam Penerapan Pasal XX (b) GATT dalam Kasus Reformulated Gasoline}

Perbedaan penafsiran yang dilakukan oleh Panel dan Appellate Body tentang penerapan Pasal XX (b) GATT sebagai berikut. Pertama, menurut Appellate Body,

${ }^{34}$ Steve Charnovitz, "The Law of Environmental 'PPMS' in the WTO: Debunking the Myth of Illegality”, Yale J. Int'l L., vol. 27, Winter, 2002, hlm.78. 
Panel dalam menafsirkan persyaratan berkaitan dengan (relating to) konservasi terhadap sumber daya alam hanya berdasarkan metode pendekatan yang bersifat tekstual saja sehingga tidak memperhatikan mengenai tujuan dan objektif dari suatu ketentuan yang dituangkan dalam GATT. Dengan demikian penafsiran yang dilakukan oleh Panel dapat dikatan sempit dan tidak komprehensif.

Sedangkan penafsiran yang dilakukan oleh Appellate Body bersifat komprehensif, dengan mengambil metode penafsiran tidak hanya berdasarkan tekstual saja tetapi juga memperhatikan tujuan dan maksud yang akan dicapai (objective and purpose) serta didasarkan pada itikad sesuai dengan arti lugas namun kontekstual. Oleh karena itu, dalam memberikan justifikasi apakah suatu ketentuan berkaitan dengan atau perlu untuk perlindungan lingkungan, harus dipahami secara keseluruhan berdasarkan keterkaitan antara tindakan dan seluruh kebijakan yang diambil dalam rangka untuk perlindungan lingkungan.

Menurut Appellate Body Pasal XX(g) GATT harus dipahami sesuai dengan tujuan dan maksud GATT. Appellate Body juga menyatakan bahwa Panel telah salah dalam menerapkan "test" terhadap penerapan pasal XX (g) GATT untuk penentuan baseline establishment rules apakah perlu (necessary) atau tidak, karena test tersebut tidak diperlukan oleh Pasal XX GATT. Adapun test yang tepat untuk penerapan frase "berkaitan dengan" (relating to) berdasarkan kasus demi kasus, dengan memperhatikan fakta dan kontek hukum secara seksama dalam kasus yang bersangkutan. Serta memperhatikan tujuan dan maksud para pihak dalam perjanjian tersebut. ${ }^{35}$

Appellate Body juga tidak sepakat dengan Panel yang menyatakan bahwa baseline establishment rules tidak secara langsung berkaitan dengan konservasi udara bersih. Sedangkan menurut Appellate Body ketentuan tentang baseline establishment rules berhubungan langsung dengan konservasi udara bersih, dan memiliki hubungan yang signifikan dengan kebijakan konservasi. Tanpa adanya baseline untuk melakukan monitoring dan control maka tujuan konservasi tidak akan tercapai, sehingga Appellate Body berpendapat bahwa baseline establishment rules masuk dalam ruang lingkup Pasal XX (g) GATT.

${ }^{35}$ Anna Beth Snoderly, "Clearing the Air: Environmental Regulation, Dispute Resolution, and Domestic Sovereignty Under the World Trade Organisation”.C.J. Int'l \& Com. Reg., vol. 22, Fall 1996, 254. 


\section{Perbedaan Penafsiran Antara Panel dan Appellate Body dalam Penerapan Pasal XX (g) GATT Dalam Kasus Shrimp-Turtle}

Panel menyatakan bahwa tindakan Amerika Serikat yang melarang masuknya produk udang berdasarkan Section 609 bertentangan dengan Pasal XI (1) GATT dan tidak dapat dibenarkan berdasarkan Pasal XX GATT. Untuk sampai pada kesimpulan ini, Panel terlebih dahulu menganalisa Section 609 berdasarkan preamble Pasal XX GATT. ${ }^{36}$

Panel berkesimpulan bahwa Section 609 tidak termasuk dalam ketentuan Pasal XX GATT, karena walaupun kondisi kura-kura laut terancam, Panel berpendapat bahwa tindakan yang dilakukan oleh Amerika Serikat melarang produk udang memasuki pasar Amerika Serikat dapat merusak dan mengancam sistem perdagangan internasional multilateral. ${ }^{37}$ Menurut Panel, kalau banyak negara yang melakukan tindakan sepihak sebagaimana yang dilakukan oleh Amerika Serikat maka hal tersebut akan merusak sistem multilateral perdagangan internasional.

Appellate Body ${ }^{38}$ tidak setuju dengan apa yang diputuskan oleh Panel. Appellate Body menyatakan bahwa Section 609 merupakan ruang lingkup Pasal XX GATT dan ketentuan itu masuk dalam Pasal XX sub-paragraf (g). ${ }^{39}$ Namun demikian, Appellate Body menyatakan bahwa Section 609 gagal untuk memenuhui persyaratan preamble Pasal XX GATT. ${ }^{40}$

Appellate Body menyatakan bahwa Section 609 memenuhi persyaratan Pasal XX subparagraf (g) GATT, karena kura-kura laut merupakan sumber daya alam yang langka (exhaustible natural resources). ${ }^{41}$ Lebih lanjut lagi Appellate Body menyatakan, walaupun ketentuan yang dimuat dalam Section 609 tersebut merupakan tindakan sepihak (unilateral) dan sertifikasi juga didasarkan pada kebijakan dan ketentuan hukum yang sama. Akan tetapi menurut Appellate Body,

\footnotetext{
${ }^{36}$ Ryan L. Winter, "Reconciling the GAT'T and WTO with Multilateral Agreement: Can We Have Our Cake and It to It ?”, vol. 11, Winter, 2000, Colo. J. Int'l Envtl. L. \& Pol'y. 232-233.

${ }^{37}$ Panel Report on US-Shrimp, n. 26. Para. 7.29.

${ }^{38}$ The Appellate Body Report on Shrimp-Turtle, n.86. Para. 187.

${ }^{39}$ Bradly Condon, "Multilateral Environmental Agreements and the WTO: Is the Sky Really Falling ?", vol. 9 (Spring, 2002) Tulsa J. Comp. \& Int'l L. 338.

${ }^{40}$ In sum, when Article XX is invoked to justify a trade policy measure with environmental implications, the first step is to examine the legitimacy of the measure's policy goal under Article XX(b) or (g). If the measure can be justified by the exceptions stipulated in the sub-paragraphs of Article XX, then the second step is to analyse the application of the measure under the chapeau's criteria. See, Dukgeun Ahn, "Environmental Dispute in the GATT/ WTO: Before and After-Shrimp Case”, vol. 20, Summer, 1999, Mich. J. Int'l L., 833.

${ }^{41}$ Ibid.
} 
ketentuan tersebut masih berkaitan dengan konservasi kura-kura laut dan diberlakukan baik untuk produk dalam negeri maupun luar negeri. ${ }^{42}$

Appellate Body menolak argumen Panel yang menyatakan bahwa, tindakan sepihak yang dilakukan oleh Amerika Serikat seperti Section 609, tidak masuk dalam ruang lingkup Pasal XXGATT. ${ }^{43}$ Dalam kasus ini Appellate Body mengulang kembali cara analisis Pasal XX GATT sebagaimana yang dilakukan dalam ReformulatedGasoline, ${ }^{44}$ yang mensyaratkan bahwa makna dan ruang lingkup (scope) Pasal XX harus ditafsirkan berdasarkan preamble dan juga sub paragraf Pasal XX tersebut.

Keputusan Appellate Body ini merupakan bukti adanya kesadaran baru bagi Appellate Body akan pentingnya penerapan prinsip pembangunan berkelanjutan dalam sistem WTO dan terintegrasi dalam Pasal XX GATT. Dapatlah dikatakan bahwa keputusan ini memberi arti tersendiri tentang prospek yang bagus terintegrasinya perlindungan lingkungan dalam sistem WTO. Keputusan Appellate Body dalam kasus Shrimp-Turtle ini merupakan hasil dari penafsiran yang progresif terhadap Pasal XX (g) GATT.

Oleh karena itu dapat disimpulkan bahwa, Appellate Body telah berhasil menerapkan metode penafsiran perjanjian internasional yang diatur dalam Pasal 31 Konvensi Wina 1969 tentang Perjanjian Internasional. ${ }^{45}$ Selain itu Badan Penyelesain Sengketa WTO telah menerapkan penafsiran perjanjian internasional sesuai dengan penafsiran yang diatur dalam hukum internasional untuk mengklarifikasi perjanjian internasional yang dimuat dalam covered agreements. ${ }^{46}$

\section{Perbedaan Penafsiran Antara Panel dan Appellate Body dalam Penerapan Pasal XX (b) GATT Dalam Kasus EC-Asbestos}

Adapun dalam kasus EC-Asbestos intepretasi Pasal XX (b) yang dilakukan oleh Panel maupun Appellate Body memiliki suatu persamaan. Dalam kasus ini baik Panel maupun Appellate Body sama-sama berpendapat bahwa Asbestos yang berasal dari Kanada dapat membahayakan kesehatan. Ini baru pertama kalinya, Panel dan Appellate Body berpendapat bahwa tindakan yang dilakukan berdasarkan Pasal XX (b) GATT adalah perlu (necessary).

\footnotetext{
${ }^{42}$ Ibid.

${ }^{43}$ Carrie Wofford, "A Greener Future at the WTO: The refinement of WTO Jurisprudence on Environmental Exception's to GAT'T”, vol. 24 (2000) Harv. Envtl. L. Rev. 248.

${ }^{44}$ Appellate Body Report on Shrimp-Turtle, n. 162. Para 105. See also, Yavitz, n. 169, at 213.

${ }^{45}$ Crosby, n. 125, at 291.

${ }^{46}$ Article 2(3), the DSU.
} 
Selain itu dalam kasus ini, justifikasi menggunakan preamble Pasal XX GATT diinterpretasikan secara komprehensif dengan memberikan perlakuan yang seimbang antara perlindungan kesehatan dan kepentingan perdagangan internasional. Oleh karena itu, dalam kasus ini baik Panel maupun Appellate Body menyatakan bahwa putusan larangan masuknya asbestos dari Kanada ke Perancis merupakan keputusan Perancis yang dibenarkan menurut Pasal XX(b) GATT.

Mula-mula Panel menilai apakah peraturan yang dikeluarkan oleh Perancis masuk dalam ruang lingkup Pasal XX(b), kemudian baru menentukan apakah ketentuan tersebut juga sesuai dengan yang dimuat dalam preamble. Menurut Panel, untuk dapat memenuhi ketentuan Pasal XX (b) GATT, maka ketentuan tersebut harus ditujukan kepada perlindungan kehidupan manusia, kesehatan dan sangat penting untuk mencapai kebijakan yang diinginkan. ${ }^{47}$

Panel menyatakan bahwa Kanada gagal untuk membuktikan bahwa keputusan yang dikeluarkan Perancis tidaklah melanggar ketentuan dalam preamble, karena tindakan tersebut tidak membedakan perlakuan terhadap produk dalam negeri maupun luar negeri. ${ }^{48}$ Akhirnya Panel berkesimpulan bahwa ketentuan yang dikeluarkan oleh pemerintah Perancis sesuai dengan ketentuan Pasal $X X(b)$ dan preamble Pasal $X X$ GATT. ${ }^{49}$ Namun demikian, argumen Panel untuk menentukan produk serupa (like product) berdasarkan ketentuan Pasal III:4 tidaklah disepakati oleh Appellate Body.

Perbedaan interpretasi yang dilakukan oleh Panel dan Appellate Body disebabkan oleh kurangnya pemahaman Panel terhadap ketentuan Pasal 3(2) DSU yang memberikan otoritas kepada Badan Penyelesaian Sengketa (Dispute Settlement Body) WTO untuk menginterpretasikan ketentuan GATT sesuai dengan ketentuan Konvensi Wina 1969 tentang Perjanjian Internasional, serta kurangnya wawasan dan keberpihakan pada kepentingan kesehatan dan perlindungan lingkungan.

\section{Penutup}

Berdasarkan penelitian terhadap putusan Panel dan Appellate Body dalam kasus Shrimp-Turtle, Refurmulated Gasoline dan EC-Asbestos yang diajukan di WTO

\footnotetext{
${ }^{47}$ Steve Charnovitz, "The Law of Environmental PPMS in the WTO: Debunking the Myth of Illegality", vol. 27, Winter, 2002, Yale J. Int'l L., 83.

${ }^{48}$ Golm Patrick Mc Inemey, "From Shrimp and Dolphins to Retreated Tyres: An Overview of the WTO Disputes, Discussing Exception to Trading Rules", vol. 22, Winter, 2009, N.Y. Int'l L. Rev., 159-160.

${ }^{49}$ Ibid.
} 
tentang penerapan Pasal XX (b) dan (g) maka diperoleh suatu kesimpulan sebagai berikut : Pertama, Panel dan Appellate Body memiliki perbedaan dalam penerapan Pasal XX (b) dan (g) GATT. Hal ini disebabkan adanya perbedaan penafsiran/ interpretasi yang yang dilakukan oleh Panel dan Appellate Body. Interpretasi yang dilakukan oleh Panel terhadap Pasal XX (b) dan (g) GATT bersifat sempit dan tekstual, sedangkan penafsiran Appllate Body bersifat komprehensif; Kedua, perbedaan penafsiran implementasi Pasal XX (b) dan (g) GATT oleh Panel dan Appellate Body dalam penyelesaian ketiga kasus tersebut disebabkan karena kurangnya pemahaman Panel terhadap cara interpretasi yang diatur dalam Pasal 2 (3) DSU dan kurang adanya keperpihakan Panel terhadap kepentingan perlindungan kesehatan, tumbuhan, hewan, dan lingkungan.

Seharusnya Panel dalam menginterpretasikan ketentuan Pasal XX (b) dan (g) GATT lebih dapat memberikan putusan yang berwawasan lingkungan. WTO sebagai organisasi perdagangan internasional mempunyai kewajiban untuk perlindungan lingkungan dan menjamin keberlangsungan perdagangan internasional sesuai dengan prinsip pembangunan berkelanjutan dan tujuan pendirian WTO yang dimuat dalam preamble Perjanjian pendirian WTO.

Selain itu perlu adanya peningkatan wawasan lingkungan kepada Badan Penyelesaian Sengketa WTO, sehingga putusan-putusan yang diambilnya akan memiliki keberpihakan kepada perlindungan lingkungan dan kesehatan manusia, serta sumber daya alam yang lain. Dengan demikian akan tercapai keseimbangan antara kepentingan perdagangan internasional dan perlindungan lingkungan.

\section{Daftar Pustaka}

Ahn, D., Comparative Analysis of the SPS and the TBT Agreements. Int. T.L.R. vol. 8, 2002.

Anjo, Lindros and Mehling Michael, "Dispelling the Chimera of Self Contained Regimes' International Law and the WTO", Eur. J.Int'l. L., vol. 16, November, 2005.

C. Ford, Runge, Francois Ortalo-Magne and Philip Vande Kamp, Freer Trade, Protected Environment Balancing Trade Liberalization and Environmental Interest, New York, Council on Foreign Relations Press, 1994.

Carrie, Wofford, "A Greener Future at the WTO: The Refinement of WTO Jurisprudence on Environmental Exception to GATT," Hrv. Envtl.L.Rev., vol. 24, 2000.

Cassese, Antonio International Law, Oxford University Press, Oxford, 2001. 
Debbie, Collier and Moitui, Charles. “Africa's Regulatory Approach to Biotechnology in Agriculture: An Opportunity to Seise Socio-Economic Concerns", (2009) vol. 17 (1) A.J.I.C.L. 31.

Daniel C., Esty, Greening the GATT: Trade Environment and the Future, Washington Institute for International Economic.

David P, Fidler, International Law and Infectious Deseases, Claredon Press, Oxford, New York, 1999.

den Bossche Peter, Van, The Law and Policy of the World Trade Organization, Text, Cases and Materials, Cambridge University Press, New York, 2005.

Eric, Neumayer, Greening Trade and Investment Environmental Protection without Protectionism, London, Earthscan Publication Ltd, 2001

Final Act Embodying the Result of the Uruguay Round of Multilateral trade Negotiations, April 15, 1994, 33 I.L.M. 1143 (1994) (hereinafter Final Act).

General Agreement on Tariffs and Trade, Oct. 30, 1947, art. XX, 61 Stat. A-11, 55 U.N.T.S. 194 [hereinafter Article XX GATT].

Hans J., Crosby, “The World Trade Organisation Appellate Body, United States v Venezuela: Interpreting the Preamble of Article XX are Possibilities for Environmental Protection Under Article XX(g) of GATT Disappearing", Vill. Envtl. L.J., vol. 91998.

inclair, Ian, The Vienna Convention on the Law of Treaties, 2nd edition, Manchester, Manchester University Press.

Iona, Cheyney, "Gateway to The Precautionary Principle in WTO Law”, J. Envtl. L., vol. 19, 2007.

Jennifer, Schultz, "The Demise of Green Protectionism: The WTO Decision on the U.S Gasoline Rule", Denv. J. Int'l L. E Pol'y., vol. 25, (Fall, 1996).

Joost, Pauwlyn, "The Limits of Litigation: Americanisation and Negotiation in the Settlement of WTO Dispute", Ohio St. J. on Disp.Resol., vol. 19, 2003.

Laurent A., Ruessmann, "Putting the Precautionary Principle in Its Place Parameter for the Proper Application of Precautionary Approach and the Implication for Developing Countries. in Light of the Doha WTO Minnisterial, Am.U.Int'l.Rev., vol. 17, 2002.

McBride, S.D., Reformulating Executive \& Legislative Relationship after Reformulated Gasoline: What is Best for Trade and the Environment?. Wm. E Mary Envtl. L. E Pol'y Rev. vol. 23. Fall, 1998

Miquel A. Elizabeth, Carranza, "MEAS with Trade Measures and the WTO: Aiming Toward Sustainable Development? “, Buff.Envtl.L.J., vol. 15, 2007-2008.

Nita, Ghei, "Evaluating the WTO Two Step Test for Environmental Measures Under Article XX" (Winter, 2007) vol. 18 Colo. J. Int'l Envtl. L. E Pol'y.

Panel Report on United States-Import Prohibitionof Certain Shrimpand Shrimp Products, WT/DS 58/R, (May,15, 1998), 37 I.L.M.832(1998), (hereinafter Shrimp-Turtle Report) 
Philippe, Sand, Principle of International Environmental Law, Manchester University Press, Manchester, 1995.

Richard, Skeen, "Will the WTO Turn Green? The Implication of Injecting Environmental Issues into the Multilateral Trading System", vol. 17 Geo. Int'l Envtl. L. Rev, Fall, 2004.

Steve, Charnovitz, "The Law of Environmental 'PPMS' in the WTO: Debunking the Myth of Illegality", Yale J. Int'l L., vol. 27, Winter, 2002.

Steve, Keane, "Can a Consumer's Right to Know Servive the WTO? The Case of Food Labelling", Transnat'l L. E Contemp. Prob., vol. 16, Fall, 2006.

Thomas M., Frank, Fairness in International Law and Institutions, Claredon Press, Oxford, New York, 1995.

United Nation General assembly Resolution (UNGA) 7, UN GAOR 36 sess. Suppl. No. 51, Un Doc. A/51 (1982).

Voigt, Cristina, Sustainable Development as a Principle of International Law Resolving Conflict between Climate Measure and WTO Law, Martinus Nijhoff Publisher, LeidenBoston, 2009.

Yuka, Fukunaga, "Securing Compliance Through the WTO Dispute settlement System: Implementation of DSB Recommendations, J. Int'l Econ. L., vol. 9, June, 2006.

Yavitz, Laura "The WTO and Environment: The Shrimp Case that Created A New World Order", Nat. Resources Envt.L., vol. 16, 2000-2001.

Panel Report on United States-Import Prohibition of Certain Shrimp and Shrimp Products, WT/DS58/R (hereinafter, Shrimp-Turtle) (May 15, 1998) 37 I.L.M.832(1998).

Appellate Body Report on United States-Import Prohibition of Certain Shrimp and Shrimp Products, WT/DS58/AB/R (hereinafter Shrimp-Turtle) (October. 12, 1998), 38 I.L.M. 118 (1999).

Panel Report on United States-Standards for Reformulated and Conventional Gasoline (WT/ $\mathrm{DS} / 2 / \mathrm{R})$

Appellate Body Report on United States-Standards for Reformulated and Conventional Gasoline (WT/Ds2/AB/R).

Panel Report on European Communities-Measures Affecting Asbestos and AsbestosContaining Products (hereinafter EC-Asbestos)WT/DS135/R (Sept. 18, 2000).

Appellate Body Report on European Communities-Measures Affecting Asbestos and Asbestos-Containing Products (hereinafter EC-Asbestos), Wt/DS135/AB/R.

Declaration of the United Nations Conference on the Human and Environment (hereinafter Stockholm Declaration).

Dispute Settlement Understanding of the WTO

General Agreement on Tariffs and Trade

Konvensi Keanekaragaman Hayati

Konvensi Hukum Laut 1982 
The Marrakesh Agreement Establishing the World Trade Organisation

The Vienna Convention on the Law of Treaties (hereinafter VCLT) 